\title{
HELPING PARENTS COPE WITH A CLEFT LIP AND PALATE
}

Jenny Steyn,

B.A. (Sp. \& H. Th.)

Speech and Hearing Therapist

\section{OPSOMMING}

Vir die leek is die gebied van 'n gesplete verhemelte in geheimsinnigheid en gebrekkige kennis gehul. 'n Gesplete lip en verhemelte wat nog nie herstel is nie is 'n onaangename en miskien selfs onstellende gesig, en ouers voel nie altyd heeltemal oortuig deur die gerusstellende woorde van dokters en verpleegsters dat plastiese chirurgie wonderlike werk aan babas met ' $n$ gesplete verhemelte doen nie. Hulle het bewys nodig dat hulle baba binne enkele maande soos enige ander baba sal lyk. Dit is ook net so belangrik dat hulle die versekering moet kry dat hulle gewaarwordings by die geboorte van die baba natuurlik en paslik is.

Namate die baba groei en ontwikkel, moet die ouers miskien praktiese hulp, emosionele steun en inligting oor hulle baba se toestand $k r y$. Dit is eintlik daarom dat ' $n$ gemeenskapsgroep onder beskerming van SAVOS (die Suid-Afrikaanse Vereniging vir Oorerflike Siektes) gestig is om ouers en gesinne van kinders met 'n gesplete lip en verhemelte te help.

$\mathbf{F}$ or the layman, the area of cleft palate is one shrouded in mystery and half-knowledge. An unrepaired cleft lip and palate is an unpleasant, if not alarming sight, and parents are not always totally convinced by the reassuring words of doctors and nurses that "plastic surgeons do a marvellous job on cleft palate babies." They need proof that their baby will indeed look and be like any other baby within a few months. Equally important, they need reassurance that whatever feelings they may experience when their babies are born are natural and appropriate ones. As the baby grows and develops parents may need practical assistance, emotional support and information regarding their baby's condition. It is essentially for these reasons that a fellowship group has been established under the auspices of SAIDA (Southern Africa Inherited Disorders Association) to help parents and families of cleft lip and palate children.

The idea for the formation of this group originated in a rather ironical situation. I am a speech therapist, and my second son, David, was born with a unilateral cleft lip and palate. My husband was with me during the birth and we both felt terribly shocked when the doctor broke the news to us. However, by the time my husband left me to go home that evening, we had got over the shock a little and were feeling quite positive about David's future. I had seen children with both repaired and unrepaired clefts and was able to reassure my husband about the results achieved by the team of proiessionals involved with cleft palate children. This helped to allay our anxiety to a considerable extent, and we both feel that if new parents could be visited immediately by parents of older cleft palate children, they could benefit a great deal. Not only photographs, but descriptions of the child's progress and expression of parents' feelings could help the new parent to feel more optimistic.

\section{Incidence and causes of clefi lip and palate}

A cleft lip and palate occurs in approximately one birth in 1000 , and differs between the sexes and in dif- ferent population groups. The majority of clefts are unilateral. Ten per cent of children with a cleft lip and palate have associated anomalies, such as club-foot.

No one factor has been found to be responsible for causing a cleft lip and palate. Rather, it is postulated that it is caused by a combination of genetic and environmental factors. The latter include a viral infection in early pregnancy, the mother's nutrition in pregnancy or certain drugs taken during the first twelve weeks of pregnancy.

\section{Feeding}

There are two schools of thought regarding the feeding of a baby with a cleft lip and palate. Many doctors favour breast-feeding for two basic reasons. The first is that the presence of antibodies in the mother's milk helps to build up the baby's resistance in preparation for surgery. The second reason is that sucking from the breast requires strenuous movements by the baby, exercise that he needs in order to develop the muscles that will later be needed for speech. This second argument for breast-feeding is one of the main reasons against it, for the cleft palate baby is often unable to suck sufficiently strongly for breast-feeding, and many people feel that an unsuccessful attempt at breastfeeding is an unnecessary frustration for both mother and baby.

I was determined to breast-feed David. I had breastfed my older son for 6 months with no trouble, and was grateful for that when trying to feed David. The first problem was to position David in such a way that milk did not run out of his nose while he was sucking. We did this by pressing the left side of the lip against the breast. David managed reasonably well, but tired quickly and had to have a bottle supplement. One of the sisters in the nursing home was particularly helpful and encouraging and I'm sure that without her I would not have had the confidence to try and feed David.

I persevered for 6 weeks but eventually had to abandon the effort as David suffered from colic which was thought to be aggravated by the combination of breast 
milk and S26. I was advised to give one or the other at each feed. I would give a bottle of S26, express breast milk every four hours, and when I had sufficient breastmilk in a bottle I would begin a feed on the breast and supplement with the bottle of breast-milk. My milk diminished quickly, David became frustrated at the breast and I began to dread feeding time - clearly, the time had come to give up breast-feeding. Feeding time then became a far more relaxed and enjoyable time for both of us, and David continued to thrive.

Special teats are available for cleft palate babies, but not many mothers use them; generally, normal teats can be adapted to suit a baby with a cleft lip and palate. This is a second area in which parents can gain support from each other. Mothers are usually told to experiment with different teats and bottles until they find the one that is most suitable for their particular baby. Exchanging suggestions with other mothers could give them practical assistance as well as the confidence which new mothers often lack to try different ideas.

We found that an extra-large hole in the teat (as was used in the nursing home) was not satisfactory for David as the milk ran out too quickly and he was inclined to choke on it. Added to this, he was not required to suck at all in order to obtain milk and as such was not exercising his oral muscles. We cross-cut his teats, making the cross larger than normal. This proved very successful as milk did not come through the teat unless David sucked on it. As his sucking became stronger, the cross in the teat was made smaller and smaller.

Introducing a normal baby to the spoon is sometimes a difficult task, and it is no easier for the mother of a cleft palate baby. In fact, it is often made more difficult because of the mother's anxiety in anticipation of the first operation after which the baby will be only spoonfed for a few days or weeks. Patience is the key here.

\section{Surgery}

Surgery to repair a cleft lip and palate is seldom, if ever, regarded as an emergency operation; rather, it is performed only when the baby is strong and healthy enough to undergo it. Of course, the parents are anxious to begin as soon as possible and this is not ignored, but the baby's health is the first priority.

There are a number of different approaches to the repair of a cleft lip and palate. On the one hand, the repair of the lip, hard palate and soft palate is performed in one procedure when the baby is a few months or even a few weeks old. At the other end of the pole is the approach which involves repair of the lip at about 3-6 months, repair of the soft palate between 12 and 18 months and closure of the hard palate at about schoolgoing age. There is a tendency recently to repair the lip and soft palate in one procedure, but whether the surgeon does this or not usually depends on his findings when he examines the baby already under anaesthetic for the lip repair. Thus, neither the surgeon nor the parents know until the last minute whether the soft palate will be included in surgery or not. A further approach is to repair the lip at about 3-6 months and the hard and soft palates at 18 months. With all these procedures, cosmetic surgery may be necessary when the child is older and the face more fully grown.

After endless discussion and a great deal of confusion, we decided on the most conservative approach, namely the three-stage approach. Although this involves at least 3 operations it does allow for some normal growth to occur before each step is performed.

\section{Lip repair}

Fortunately David gained weight well and steadily and surgery to repair the lip was done when he was just over 3 months old and weighed 11 lbs. It was traumatic having to leave him in the hospital, although we left him smiling and gurgling. He was admitted 2 days before the operation was scheduled, to allow time for the necessary tests and for him to become accustomed to the nursing staff.

He was in the theatre for 3 hours. When we were eventually called up to the ward to see him, we could not believe how beautiful he looked. He was moaning a little but was quite alert, and his whole little face looked different.

David was taken off solid foods and fed milk with a spoon four-hourly. At first he screamed through each feed but gradually accepted the spoon more readily. His arms were in splints to prevent him sucking his fingers. This proved to be very frustrating for him - he was accustomed to sleeping on his stomach and had begun to suck his thumb; now he was forced to sleep on his back with his arms at his sides.

We brought David home after a week in the hospital and continued with spoon-feeding and the splints for approximately two weeks. The orthondontist felt that we should take advantage of the splints to stop David sucking his thumb, so as soon as the surgeon was satisfied, we gave him a dummy and returned the bottle to him.

\section{Repair of soft palate}

The plastic surgeon decided to do the soft palate repair when David was just over 8 months old. Unfortunately, 2 hours before he was due to go into theatre, David's temperature began rising, and the operation was postponed for a month.

After this operation David was again not allowed to suck for a few weeks. I began to wean him off the bottle and onto a feeding cup at the age of about 7 months, and he took it quite happily. We decided not to attempt to take his dummy away until after the operation, when the doctors felt that he would probably be too uncomfortable to suck it. He has had neither a bottle nor a dummy since. His arms were splinted again.

Adequate functioning of the soft palate is very important for good speech development so that there is good velar-pharyngeal closure to separate the oral and nasal cavities. The repair to David's soft palate seems to have been successful.

\section{Ear Infections}

Cleft palate children are prone to upper respiratory tract and ear problems, mainly due to inadequate 
functioning of the eustachian tube. David is no exception - he has had recurrent middle ear infection and had his ears drained and grommets inserted at the age of 7 months. The grommets are tiny tubes inserted in the tympanic membrance, and they serve to drain the middle ear when pus accumulates there, as well as to ventilate the middle ear, the functions that the eustachian tube fails to perform adequately.

\section{General Development}

Apart from his cleft lip and palate David is like any other baby. He sat at 8 months, never crawled, but now at the age of 16 months is able to pull himself up and stand without support for a short while. His first tooth appeared when he was 11 months old and he now has 5 teeth, 2 lower and three upper. His upper teeth are not correctly positioned and one is lying in the line of the cleft but we anticipated this and it will be rectified with orthodontic treatment at a later stage.

Of course I have watched his speech development closely, hopefully without undue anxiety. He babbled like any other baby and now (16 months) has a vocabulary of about 15-20 words which his family understands. He began with words containing the nasal sounds, which are obviously easiest for cleft palate children, e.g. mama, no, and then moved on to l, w and $y$ sounds in words. He still babbles incessantly and attempts to imitate the sound effects his older brother uses in his games.

On the whole David has been an easy and happy baby and I'm sure that we will remember the trauma of his first year longer than he will!

\section{Aims of our Group}

1. Our main objective is for parents of cleft palate children to help each other on the basis of similar experiences both practical and emotional.

2 . We would like to reach new parents as soon as possible after their cleft palate baby is born, to show and reassure them that their babies will be like other children within a relatively short time. At this stage, they may also need recognition of their feelings, whether these be ones of guilt, depression, blame or whatever and it may help to share these with other parents who went through similar emotions.

3 . Until the baby has settled into a routine and the mother feels more relaxed and ready to face the world, meeting with a group of other mothers may be a little overwhelming and therefore, mothers will be available to offer individual advice and assistance.

4. When the mother feels emotionally ready, she may join an informal group in which mothers exchange ideas and share experience. From time to time a short lecture on a specific subject may be arranged, if the mothers require it.

5. Every 4-6 months a meeting of all parents will be arranged and this will take the form of a lecture, slide show or panel discussion. This will help to include fathers who are so often neglected.

6. A newsletter will be issued to all interested parents and others approximately every three months. This will include a summary of what takes place at the mothers' group meetings, items of specific interest and hopefully contributions from parents and their children. Many parents interested in our group live away from big cities, and it is felt that regular newsletters will keep them in touch with other parents.

\section{Role of the nurse}

We visualise the nurse, or perhaps more specifically the community health nurse as having an important role to play in helping the parents of cleft palate children. Immediately after the baby is born, the nurse is the person who has the most frequent contact with the mother; it is her task to help the mother establish feeding of the baby, as well as to cope with her emotional reaction. This is often a difficult situation and one in which many people are inexperienced and unsure of how to cope.

When mother and baby leave the nursing home, the community health nurse steps in and she has a number of valuable tasks to perform. In the early months, parents of cleft palate children tend to forget that their babies are like others, and as such require the regular treatment provided by the health clinics, such as weighing, immunisation and so on. As mentioned earlier, cleft palate babies have a propensity for upper respiratory problems, and their hearing should be periodically tested. The community health nurse could remind parents of this.

The community health nurse, with her knowledge and experience in feeding, could be of great assistance to the mother of a cleft palate baby, not only as regards what to feed, but also how to do so.

A number of cleft palate babies are born in outlying areas where there is no easy access to large hospitals and probably no other cleft palate baby for miles. In these areas, where there are no older parents for new parents to contact, the community health nurse would be the person most likely to fill the gap. She would have to be available to offer practical suggestions and advice as well as to help the parents cope with any other problems. She may be aware of other parents with cleft palate children not too far away and if possible, could arrange for them to meet each other from time to time.

The community health nurse is aware of the wide circle of professionals available to help the cleft palate child, should specific difficulties arise. These people include the orthodontist, plastic surgeon, speech therapist and social worker.

Being told that one has just given birth to a child with a cleft lip and palate is a shock. Then follows worry about feeding the baby, hours of consultations with doctors, anxiety regarding surgery, concern about speech development and so on. And yet, the outlook for a cleft palate child is usually a bright and positive one. The parents need not be weighed down or burdened in the child's first few years. With information, practical assistance and emotional support their load can be considerably lightened.

Further information regarding the group and its activities can be obtained from the writer at: 25 Second Road, Kew, Johannesburg 2090. Telephone: 786-8239. 